\title{
A research note on the determinants and consequences of outsourcing using German data
}

\author{
John T. Addison · Lutz Bellmann • André Pahnke • \\ Paulino Teixeira
}

Accepted: 21 April 2011 / Published online: 12 May 2011

(C) Institut für Arbeitsmarkt- und Berufsforschung 2011

\begin{abstract}
Using German data from the Institute for Employment Research Establishment Panel, this paper constructs two main measures of outsourcing and examines their determinants and consequences for employment. There are some commonalities in the correlates of the two measures of outsourcing, as well as agreement on the absence of adverse employment effects across all industries. For one specification, however, some negative effects are reported for manufacturing industry, balanced by positive effects for the services sector for another. But there are no obvious indications of survival bias. This is because the association between outsourcing and plant closings is predominantly negative, albeit poorly determined.
\end{abstract}

Keywords Outsourcing - Organizational change · Employment change $\cdot$ Plant closings $\cdot$ Value added

JEL Classification F16 $\cdot$ J23

\section{J.T. Addison ( $₫)$}

Department of Economics, Moore School of Business,

University of South Carolina, Columbia, SC 29208, USA

e-mail: ecceaddi@moore.sc.edu

J.T. Addison · P. Teixeira

IZA, Bonn, Germany

L. Bellmann

Institut für Arbeitsmarkt- und Berufsforschung,

Bundesagentur für Arbeit, Department of Economics,

University Erlangen-Nuremberg, Nuremberg, Germany

\section{A. Pahnke}

Institut für Arbeitsmarkt- und Berufsforschung

der Bundesagentur für Arbeit, Nuremberg, Germany

P. Teixeira

Faculdade de Economia, Universidade de Coimbra, Coimbra,

Portugal

\section{Einige Bemerkungen zu den Bestimmungsgründen und Auswirkungen von Outsourcing auf Basis deutscher Daten}

Zusammenfassung Auf der Basis der Daten des IABBetriebspanels werden in dem Papier zwei Outsourcing- Indikatoren gebildet und die Determinanten dafür sowie die Beschäftigungseffekte untersucht. Beide Indikatoren weisen Gemeinsamkeiten bei den Korrelationen mit anderen Variablen auf. In keinem Fall zeigen sich in unseren Regressionsmodellen für alle Wirtschaftszweige negative Beschäftigungseffekte. Bei einer Modellspezifikation werden jedoch negative Beschäftigungseffekte für das Verarbeitende Gewerbe, aber auch positive Beschäftigungseffekte für den Dienstleistungssektor bei einer anderen Modellspezifikation ermittelt. Wir finden auch keine Hinweise auf Verzerrungen, die durch das Überleben der Betriebe bestimmt sind. Dies liegt daran, dass für die Beziehung zwischen Outsourcing und Betriebsschließungen ein im Wesentlichen negativer Zusammenhang besteht, der allerdings nur schwach ausgeprägt ist.

\section{Introduction}

The practice of international outsourcing or offshoring of parts of the production process, especially to low-wage countries in Central and Eastern Europe, is very much in vogue. For the West German manufacturing sector in particular, it has been found that firms which have outsourced part of their production and services to foreign firms are larger and more productive, pay higher wages and have a higher export share (Wagner 2009). Research on the correlates and consequences of outsourcing using establishment data is uncommon in the literature, which indeed has mostly relied upon industry-level data in discussing the phenomenon in 
an international trade context (see Amiti and Wei 2005; Feenstra and Hanson 1999; Hijzen et al. 2005). ${ }^{1,2}$ In any event, the backdrop to our study is, therefore, a continuing paucity of studies using German micro data of any kind, with the notable exceptions of papers by Becker et al. (2005a, 2005b), Becker and Muendler (2008), Görzig et al. (2005), and Wagner (2009). And, returning to the international context, there are only a few investigations that distinguish between the manufacturing and the service sectors. Abramovsky and Griffith (2006) consider the impact of information and communication technology as an influential factor in the firm's business service outsourcing decision. Our distinction between manufacturing and service reveals some interesting preliminary insights in this regard.

But more generally, the present treatment takes a different track in examining the determinants and consequences of outsourcing. Specifically, it uses German data from the Institute for Employment Research (Institut für Arbeitsmarktund Berufsforschung, or IAB) Establishment Panel to investigate the role of plant characteristics in determining (two measures of) outsourcing and the role of outsourcing in employment change and plant survival. The consideration of plant survival assists our understanding of the effects of outsourcing on employment since it may either encourage the persistence of firms or indicate subsequent market difficulties. Our empirical discussion of outsourcing and plant closure does not point to any obvious survival bias.

\section{Measuring outsourcing at establishment level}

The IAB Establishment Panel was initiated in 1993 (1996 for eastern Germany). It contains around 16,000 establishments. Data are collected in personal interviews with the owners or senior managers of the establishment by professional interviewers. The questions cover such themes as the number of employees and their qualifications, the number of temporary and agency workers, working hours (every second year since 2002), coverage by a collective agreement at industry or firm level, establishment sales turnover, the expected development of turnover, the share of sales attributed to intermediate inputs and external costs (which we use to construct our first measure of outsourcing), export share, the share of total investment (comprising both expansion investments and, until 2007, investments in information and communications technology), the total wage bill, profit

\footnotetext{
${ }^{1}$ For studies using micro data, however, see Görg et al. (2008a, 2008b), and Görg and Hanley $(2005,2007)$. Whereas these studies focus on international outsourcing, Girma and Görg (2004) and Görg and Hanley (2004) consider the determinants and effects of outsourcing in general (see also Görzig et al. 2005; Ohnemus 2009; Broedner et al. 2009).

${ }^{2}$ The problem with firm-level data is that the effect of acquiring establishments from other firms may counteract any observed tendency toward outsourcing on the part of the (acquiring) firm.
}

sharing (irregularly in the five surveys since 1998 but comparably since 2000), together with the technological status of the establishment (except in 2004), its legal status and corporate form, age, and overall economic performance, reorganization measures undertaken and process/product innovations introduced (every third year), and company further training activities (every other year). Since 2000 the works council status of the plant has been asked every year after an hiatus in the 1990s, and (for 2006 alone) the quality of the works council from the perspective of the manager respondent. Further, the second outsourcing variable used in the present exercise is taken from a question on major organizational change including whether or not the establishment had increased its purchases of products/services from outside sources over the course of the preceding two years. This question was initiated in 1998 and has been asked every third year from 2001. These variables have been used to construct regressors in dynamic labor demand equations in the usual manner (e.g. Bellmann and Pahnke 2006; Addison et al. 2008).

As we have intimated, the key outsourcing measures contained in the IAB Panel pertain to the share of sales attributed to intermediate inputs and external costs (in the year preceding the survey $)^{3}$ and organizational change over the course of the preceding two years involving a greater acquisition of goods and services (i.e. from outside the firm). ${ }^{4}$ Specifically, the former share is converted to an absolute (Euro) value and then expressed as a share of value added. We note parenthetically that we also experimented with using the answers to this question directly, expressing the derived value of externally sourced inputs as a percentage of the total wage bill after Görg and Hanley (2005). Unfortunately asking respondents to estimate a 'share of $\mathrm{X}$ in $\mathrm{Y}$ ' variable is problematic, leading as it does to back-of-theenvelope calculations on the part of the respondent. Not surprisingly the results of using such measures are mixed; examples are available from the authors upon request.

\footnotetext{
${ }^{3}$ The actual survey question is as follows: "What share of sales was attributed to intermediate inputs and external costs [in the previous year], i.e. all raw materials and supplies purchased from other businesses and institutions, merchandise, wage work, external services, rents and other costs (e.g. advertising and agency expenses, travel costs, commissions, royalties, postal charges, insurance premiums, testing costs, consultancy fees, bank charges, contributions to chambers of trade and commerce and professional associations)?

${ }^{4}$ Readers familiar with the IAB Firm Panel should note that another question in the survey (Q2) seemingly offers a more direct measure of outsourcing since it asks whether parts of the establishment were closed down or relocated in other company units or hived off and operated as separate independent businesses. Unfortunately, there are problems in using this question-as well as a separate follow-up insourcing question (Q3) - by reason of a low response rate as well as certain inconsistencies involving the responses of single-plant firms. On closer inspection, it emerges that Q2 was never intended to inform on the outsourcing question.
} 
We used the value of externally sourced inputs as a share of value added in both levels and differences, while recognizing that changes in the ratio need not necessarily represent changes in outsourcing but may instead reflect changes in either input or output prices-as well as how establishments manage their inventories of finished goods.

Our second measure of outsourcing is in principle unaffected by changes in either input or output prices since it merely inquires of the manager respondent whether or not there was increased reliance on bought-in products and services over a two-year interval. This measure although innovative has the downside that we do not know the magnitudes in question (viz. the degree of outsourcing) merely the directional influence.

By way of summary, our two broad measures of outsourcing are not without blemish. The virtue of the former measure is that we can observe the current level of outsourcing, even if we must remain cautious about measured changes in outsourcing derived from differences in levels. The second measure allows us to identify outsourcing establishments without conveying any information about the extent of the process. Expressed differently, given the noncontiguous timing of the surveys, we cannot use information on increased reliance on outsourcing from the organizational change question to identify an acceleration or deceleration of outsourcing over time.

We use a common set of covariates for the determinants and consequences of outsourcing. These comprise sales per employee (measured in units of thousand euro (kEUR)), the share of sales attributable to exports, expectations of rising future sales, dummies for investment in information and communication technology and investment in production facilities, an advanced state of technology dummy constructed from a five-element question where the management respondent is asked to assess the plant's overall state of on technology relative to other establishments in the same industry, number of employees, wages per employee (kEUR), the shares of high-skilled workers and workers on fixed-term contracts, the separation or labor turnover rate, works council presence, ${ }^{5}$ coverage by a collective agreement at either sectoral or plant level, and whether the plant was located in western (as opposed to eastern) Germany. In addition, a number of plant characteristics were included, namely, dummies indicating if the plant was established before 1990, whether it was a single-establishment firm, and the exact legal form of the enterprise. ${ }^{6}$ Finally, our regressions include

\footnotetext{
${ }^{5}$ Since works councils may only be formed in establishments with at least five permanent employees, our sample excludes plants employing fewer than this number of employees.

${ }^{6}$ We distinguish between sole traders (the omitted category), partnerships, limited liability corporations, companies limited by shares, public corporations/foundations, and other legal forms (e.g. cooperatives).
}

in excess of 30 industry dummies, where the exact number depends on the dependent variable. We restricted our sample period mainly to the interval 2002-2004, extended to 2006 for the survival component of the analysis. ${ }^{7}$ (Variable definitions and descriptive statistics are provided in Tables 7 and 8 , respectively.)

\section{Findings}

Results on the determinants of outsourcing are provided in Tables 1 and 2. Table 1 presents logit results for the 'organizational change' measure, namely, expanded usage of bought-in products over the two-year interval ending on June 30, 2004. (Marginal effects of the covariates on the indicator variable appear alongside the coefficient estimates.) Plants with increasing recourse to outsourcing can be seen to be disproportionately export-led, to have made investments in information and communications technology, to have expectations of expanded business volume over the course of the current year, and to be located in western Germany. They also record higher labor turnover. Outsourcing is also higher in limited liability corporations than other legal forms, but single-plant enterprises clearly engage in less outsourcing. Despite the importance of investments in information and communications technology - here corroborating the results obtained by Abramovsky and Griffith 2006-there is no indication that the technological status of the plant matters, or that mature plants outsource more. On this measure, neither industrial relations institution (viz. works councils and collective bargaining coverage) nor workforce characteristics seem to influence outsourcing. ${ }^{8}$

Material on the other measure of outsourcing is contained in Table 2. The first two columns give results for the ratio of externally sourced inputs to value added in levels form for 2002 and 2004. The third column presents findings for changes in that ratio between 2002 and 2004. Beginning with the levels results, the first observation to make is that, with the exception of number of employees, no variable is consistently statistically significant. Second, while a number of variables achieve statistical significance in either yearexamples include investments in production facilities, stateof-the-art technology (not surveyed in 2004), location in western Germany, share of fixed-term contract workers, and single-firm establishments- there are also some sign reversals (e.g. export share in 2004 where the coefficient estimate

\footnotetext{
${ }^{7}$ We also investigated other time intervals (e.g. 1999-2001). Results are available from the authors upon request.

${ }^{8}$ In addition to the estimates presented in Tables 1 and 2, we examined the determinants of outsourcing by sector. The results for services and manufacturing were very similar with the major exception of the export share variable which was statistically significant for manufacturing industry alone.
} 
Table 1 The determinants of outsourcing, organizational change measure: expanded use of bought-in products and services, 2002-2004, logit model

Notes: Right-hand side variables are base-year (2002)

characteristics. The model also includes 31 industry dummies

${ }^{*},{ }^{* *}$, and ${ }^{* * *}$ denote statistical significance at the $10 \%, 5 \%$, and $1 \%$ levels, respectively. Robust standard errors are in parentheses

\begin{tabular}{|c|c|c|}
\hline Variable & Coefficient (s.e.) & Elasticities (s.e.) \\
\hline Sales per employee & $-0.0001(0.0003)^{*}$ & $-0.072(0.044)$ \\
\hline Export share & $0.007(0.002)^{* * *}$ & $0.047(0.016)^{* * *}$ \\
\hline Increasing sales expected & $0.278(0.110)^{* *}$ & $0.048(0.018)^{* * *}$ \\
\hline Investments in ICT & $0.369(0.127)^{* * *}$ & $0.165(0.057)^{* * *}$ \\
\hline Investments in production facilities & $0.139(0129)$ & $0.061(0.056)$ \\
\hline State-of-the-art technology & $-0.114(0.106)$ & $-0.069(0.065)$ \\
\hline Number of employees & $0.075(0.068)$ & $0.237(0.166)$ \\
\hline Wages per employee & $0.080(0.068)$ & $0.133(0.111)$ \\
\hline Share of high-skilled workers & $0.251(0.219)$ & $0.145(0.126)$ \\
\hline Separation rate & $0.653(0.372)^{*}$ & $0.033(0.019)^{*}$ \\
\hline Share of fixed-term workers & $-0.041(0.490)$ & $-0.001(0.016)$ \\
\hline Works council & $0.231(0.145)$ & $0.061(0.038)$ \\
\hline Collective agreement & $-0.072(0.116)$ & $-0.033(0.053)$ \\
\hline Western Germany & $0.315(0.127)^{* *}$ & $0.163(0.065)^{* *}$ \\
\hline Establishment founded before 1990 & $0.103(0.118)$ & $0.055(0.063)$ \\
\hline Single-establishment firm (without subsidiaries) & $-0.280(0.117)^{* *}$ & $-0.190(0.080)$ \\
\hline Legal form (omitted category: sole trader) & & \\
\hline Partnership & $0.223(0.225)$ & $0.019(0.018)$ \\
\hline Limited liability corporation & $0.301(0.174)^{*}$ & $0.161(0.092)^{*}$ \\
\hline Company limited by shares & $0.036(0.274)$ & $0.001(0.010)$ \\
\hline Public corporation & $-0.446(1.116)$ & $-0.002(0.004)$ \\
\hline Other legal form & $-0.391(0.523)$ & $-0.006(0.008)$ \\
\hline Log likelihood & \multicolumn{2}{|c|}{-1526.244} \\
\hline LR Chi-square (d.f.) & \multicolumn{2}{|c|}{$340.57^{* * *}$} \\
\hline Pseudo $R^{2}$ & \multicolumn{2}{|c|}{0.1077} \\
\hline$N$ & \multicolumn{2}{|c|}{4504} \\
\hline
\end{tabular}

changes from positive and statistically insignificant to negative and statistically significant). Third, there are few commonalities with Table 1; for example, expectations of higher sales in 2002 and a higher export share in 2004 are now associated with a reduced ratio of externally sourced inputs to value added. For their part, the results in the third column of the table indicate almost no statistically significant determinants of (changes in) the outsourcing ratio-and a disappointingly low coefficient of determination. The sole exceptions are companies limited by shares and the share of high-skilled employees, where the associations are positive and negative, respectively.

Summarizing our findings with respect to the determinants of outsourcing, there are few signs from the evidence on changes in outsourcing at least that the phenomenon is associated with reduced sales per employee, technological sluggishness, or low-wage firms. Although there is some supporting evidence from the analysis in levels of variables (e.g. the positive influence of state-of-the-art technology and investments in production facilities), there are also some contrary indications (the negative and marginally statisti- cally significant coefficient estimate for wages per employee in 2004). On balance, then, we might have expected to draw on more direct evidence than we have uncovered (i.e. beyond the positive associations with export share, expected sales, and investments in information and communications technology and here only for one of the outsourcing measures). And, although outsourcing might be viewed as an alternative form of workforce flexibility, note that the inverse association between the share of fixed-term workers and outsourcing was never statistically significant in the change in outsourcing equations (only for outsourcing in levels for 2002).

What of the consequences of outsourcing? To examine this question our principal focus is upon (two-year) changes in employment. But since employment changes can only be observed for survivors, we shall also consider a possible employment effect operating through plant closings. Table 3 contains OLS estimates of the effect of outsourcing on the change in employment between 2002 and 2004. Column (1) gives results for the organizational change measure of outsourcing, column (2) for the ratio of externally 
Table 2 The determinants of outsourcing, ratio of externally sourced inputs to value added measure in levels $(2002,2004)$ and changes in levels (2002-2004), OLS estimates

Notes: See Table 1. The

dependent variable in

columns (1) and (2) is given by the ratio of externally sourced inputs to value added in 2002 and 2004, respectively, and in column (3) by the 2002-2004 change in the ratio. The right-hand side variables are measured as of 2002, 2004, and 2002, respectively

${ }^{*},{ }^{* *}$, and ${ }^{* * *}$ denote statistical significance at the $10 \%, 5 \%$, and $1 \%$ levels, respectively. Robust standard errors are in parenthesis

\begin{tabular}{|c|c|c|c|}
\hline Variable & (1) & (2) & (3) \\
\hline \multirow[t]{2}{*}{ Sales per employee } & 0.0005 & $0.002^{* *}$ & -0.00002 \\
\hline & $(0.0004)$ & $(0.001)$ & $(0,0001)$ \\
\hline \multirow[t]{2}{*}{ Export share } & 0.002 & $-0.007^{* *}$ & -0.002 \\
\hline & $(0.005)$ & $(0.003)$ & $(0.006)$ \\
\hline \multirow[t]{2}{*}{ Increasing sales expected } & $-0.301^{*}$ & -0.066 & 0.430 \\
\hline & $(0.163)$ & $(0.215)$ & $(0.263)$ \\
\hline \multirow[t]{2}{*}{ Investments in ICT } & -0.005 & -0.266 & 0.038 \\
\hline & $(0.238)$ & $(0.211)$ & $(0.311)$ \\
\hline \multirow[t]{2}{*}{ Investments in production facilities } & $0.381^{*}$ & 0.275 & -0.267 \\
\hline & $(0.214)$ & $(0.203)$ & $(0.308)$ \\
\hline \multirow[t]{2}{*}{ State-of-the-art technology } & $0.301^{*}$ & & -0.141 \\
\hline & $(0.173)$ & & $(0.258)$ \\
\hline \multirow[t]{2}{*}{ Number of employees } & $0.141^{*}$ & $0.231^{* *}$ & -0.122 \\
\hline & $(0.089)$ & $(0.107)$ & $(0.127)$ \\
\hline \multirow[t]{2}{*}{ Wages per employee } & -0.089 & $-0.206^{*}$ & 0.020 \\
\hline & $(0.103)$ & $(0.106)$ & $(0.106)$ \\
\hline \multirow[t]{2}{*}{ Share of high-skilled workers } & 0.289 & -0.205 & $-1.168^{* *}$ \\
\hline & $(0.349)$ & $(0.404)$ & $(0.522)$ \\
\hline \multirow[t]{2}{*}{ Separations rate } & 0.030 & 0.243 & -0.060 \\
\hline & $(0.536)$ & $(0.170)$ & $(0.764)$ \\
\hline \multirow[t]{2}{*}{ Share of fixed-term workers } & $-0.950^{* *}$ & -0.190 & 0.257 \\
\hline & $(0.390)$ & $(0.661)$ & $(0.573)$ \\
\hline \multirow[t]{2}{*}{ Works council } & -0.432 & -0.115 & 0.488 \\
\hline & $(0.287)$ & $(0.305)$ & $(0.364)$ \\
\hline \multirow[t]{2}{*}{ Collective agreement } & -0.039 & 0.001 & 0.085 \\
\hline & $(0.248)$ & $(0.212)$ & $(0.304)$ \\
\hline \multirow[t]{2}{*}{ Western Germany } & -0.057 & $0.310^{*}$ & 0.170 \\
\hline & $(0.232)$ & $(0.173)$ & $(0.332)$ \\
\hline \multirow[t]{2}{*}{ Establishment founded before 1990} & -0.006 & -0.116 & -0.094 \\
\hline & $(0.210)$ & $(0.168)$ & $(0.312)$ \\
\hline \multirow[t]{2}{*}{ Single-establishment firm (without subsidiaries) } & $-0.461^{*}$ & -0.281 & -0.111 \\
\hline & $(0.252)$ & $(0.232)$ & $(0.338)$ \\
\hline \multicolumn{4}{|l|}{ Legal form (omitted category: sole trader) } \\
\hline \multirow[t]{2}{*}{ Partnership } & 0.423 & $-0.703^{* * *}$ & -0.687 \\
\hline & $(0.426)$ & $(0.243)$ & $(0.518)$ \\
\hline \multirow[t]{2}{*}{ limited liability corporation } & -0.219 & 0.082 & 0.063 \\
\hline & $(0.254)$ & $(0.270)$ & $(0.378)$ \\
\hline \multirow[t]{2}{*}{ Company limited by shares } & $-1.261^{* * *}$ & 0.848 & $2.939^{* *}$ \\
\hline & $(0.438)$ & $(0.768)$ & $(1.143)$ \\
\hline \multirow[t]{2}{*}{ Public corporation } & -0.644 & -0.638 & -0.080 \\
\hline & $(0.411)$ & $(0.414)$ & $(0.450)$ \\
\hline \multirow[t]{2}{*}{ Other legal form } & 1.548 & $-0.694^{*}$ & -2.380 \\
\hline & (1.432) & $(0.362)$ & $(2.176)$ \\
\hline$R^{2}$ & 0.07 & 0.08 & 0.02 \\
\hline$N$ & 5,027 & 5,643 & 3,495 \\
\hline
\end{tabular}


Table 3 The effect of outsourcing on employment change, 2002-2004, OLS estimates
Notes: See Table 1. The model includes 35 industry dummies ${ }^{*},{ }^{* *}$, and ${ }^{* * *}$ denote statistical significance at the $10 \%, 5 \%$, and $1 \%$ levels, respectively. Robust standard errors are in parentheses

\begin{tabular}{llll}
\hline Variable & Specification & \\
\cline { 2 - 2 } & $(1)$ & $(2)$ & $(3)$ \\
\hline
\end{tabular}

Expanded use of bought-in products and services, 2002-2004

0.009

Ratio of externally sourced inputs to value added, 2002

Change in ratio of externally sourced inputs to value added,

2002-2004

Sales per employee

Export share

Increasing sales expected

Investments in ICT

Investments in production facilities

State-of-the-art technology

Establishment size 21-100

Establishment size 101-1,000

Establishment size 1,001 and more

Wages per employee

Share of high-skilled workers

Separations rate

Share of fixed-term workers

Works council

Collective agreement

Western Germany

Establishment founded before 1990

Single-establishment firm (without subsidiaries)

Legal form (omitted category: sole trader)

Partnership

Limited liability corporation

Company limited by shares

Public corporation

Other legal form

$R^{2}$

$N$
0.001

(0.0004)

(0.014)$$
(0.0004)
$$$$
-0.001
$$$$
(0.001)
$$$$
-2.83 \mathrm{e}-06 \quad-4.05 \mathrm{e}-06 \quad 4.48 \mathrm{e}-07
$$$$
(6.03 \mathrm{e}-06) \quad(6.06 \mathrm{e}-06) \quad(5.75 \mathrm{e}-06)
$$$$
-0.00005 \quad-6.05 \mathrm{e}-06 \quad-0.00003
$$$$
\begin{array}{lll}
(0.0002) & (0.0002) & (0.0003)
\end{array}
$$$$
0.058^{* * *} \quad 0.057^{* * *} \quad 0.055^{* * *}
$$$$
\begin{array}{lll}
(0.010) & (0.011) & (0.011)
\end{array}
$$$$
0.050^{* * *} \quad 0.052^{* * *} \quad 0.050^{* * *}
$$$$
\begin{array}{lll}
(0.010) & (0.011) & (0.011)
\end{array}
$$$$
0.038^{* * *} \quad 0.040^{* * *} \quad 0.037^{* * *}
$$$$
\begin{array}{lll}
(0.010) & (0.010) & (0.011)
\end{array}
$$$$
\begin{array}{lll}
0.017^{*} & 0.018^{*} & 0.013
\end{array}
$$$$
\begin{array}{lll}
(0.009) & (0.010) \quad(0.010)
\end{array}
$$$$
\begin{array}{lll}
(0.012) & (0.012) & (0.012)
\end{array}
$$$$
-0.053^{* * *}-0.063^{* * *} \quad-0.048^{* * *}
$$$$
\begin{array}{lll}
(0.016) & (0.017) \quad(0.017)
\end{array}
$$$$
-0.056^{* *} \quad-0.069^{* * *} \quad-0.040
$$$$
\begin{array}{lll}
(0.022) & (0.031) \quad(0.033)
\end{array}
$$$$
\begin{array}{lll}
-0.007 & -0.007 & -0.011
\end{array}
$$$$
\begin{array}{lll}
(0.006) & (0.006) & (0.006)
\end{array}
$$$$
\begin{array}{lll}
-0.022 & -0.019 & -0.008
\end{array}
$$$$
\begin{array}{lll}
(0.019) & (0.019) & (0.020)
\end{array}
$$$$
\begin{array}{lll}
0.058 & 0.059 & -0.023
\end{array}
$$$$
\begin{array}{lll}
(0.037) & (0.038) & (0.079)
\end{array}
$$$$
0.092^{* *} \quad 0.110^{* *} \quad 0.119^{* *}
$$$$
\begin{array}{lll}
(0.050) & (0.044) \quad(0.046)
\end{array}
$$$$
\begin{array}{lll}
-0.007 & -0.001 & -0.013
\end{array}
$$$$
\begin{array}{lll}
(0.013) & (0.013) & (0.014)
\end{array}
$$$$
\begin{array}{lll}
-0.011 & -0.012 & -0.003
\end{array}
$$$$
\begin{array}{lll}
(0.010) & (0.010) & (0.011)
\end{array}
$$$$
0.028^{* * *} \quad 0.029^{* * *} \quad 0.027^{* *}
$$$$
\begin{array}{lll}
(0.010) & (0.011) & (0.011)
\end{array}
$$$$
\begin{array}{lll}
-0.014 & -0.010 & -0.012
\end{array}
$$$$
\begin{array}{lll}
(0.010) & (0.010) & (0.010)
\end{array}
$$$$
\begin{array}{lll}
-0.012 & -0.016 & -0.006
\end{array}
$$$$
\begin{array}{lll}
(0.011) & (0.011) & (0.012)
\end{array}
$$$$
\begin{array}{lll}
0.003 & 0.002 & -0.006
\end{array}
$$$$
\begin{array}{lll}
(0.017) & (0.018) & (0.018)
\end{array}
$$$$
\begin{array}{lll}
0.015 & 0.015 & 0.007
\end{array}
$$$$
\begin{array}{lll}
(0.013) & (0.013) & (0.014)
\end{array}
$$$$
\begin{array}{lll}
0.006 & 0.003 & -0.006
\end{array}
$$$$
\begin{array}{lll}
(0.024) & (0.025) & (0.027)
\end{array}
$$$$
\begin{array}{lll}
0.087 & 0.055 & 0.064
\end{array}
$$$$
\begin{array}{lll}
(0.068) & (0.073) & (0.083)
\end{array}
$$$$
\begin{array}{lll}
-0.013 & -0.023 & 0.007
\end{array}
$$$$
\begin{array}{lll}
(0.035) & (0.037) & (0.039)
\end{array}
$$$$
\begin{array}{lll}
0.05 & 0.06 & 0.07
\end{array}
$$

$\begin{array}{lll}4,541 & 4,313 & 3,495\end{array}$$$
\begin{array}{lll}
-0.007 & -0.008 & -0.004
\end{array}
$$ 
sourced inputs to value added in 2002, and column (3) for the change in this ratio between 2002 and 2004. As is apparent, the effects of outsourcing are always statistically insignificant. ${ }^{9}$ As far as the other arguments are concerned, employment change is negatively associated with establishment size, while it is positively associated with the dummies capturing investments in information and communications technology and investment in production facilities, expectations of increased sales, advanced technology, location in western Germany and, interestingly, with the share of fixedterm contract workers.

Tables 4 and 5 provide disaggregated results for services and manufacturing, respectively. For services, although the outsourcing coefficient estimates are unchanged (albeit statistically insignificant) for the ratio measures, we obtain a positive and statistically significant coefficient estimate for the organizational change measure of outsourcing. This is the first estimate of which we are aware that points to rising employment in association with outsourcing in this sector. The influence of the other regressors is broadly as observed for industry as a whole.

The results for manufacturing are differentiated from those obtained for services. Specifically, we obtain statistically significant negative coefficient estimates for the change in the ratio of externally sourced inputs to value added, but not for this ratio and for the organizational change measure. The rest of the results are also somewhat different from before. For example, the share of workers on fixedterm contracts is statistically significant, whereas the variable for the establishment founded before 1990 becomes negatively significant at the $10 \%$ level. There is also some suggestion that the very largest firms and not just larger firms have lower employment growth rates than their smaller counterparts.

As a final exercise, we sought to determine whether our outsourcing measures had any effect on plant closings. ${ }^{10}$ Since the latest (publicly) available survey refers to 2006, this exercise amounts to examining the effects of outsourcing on plant failures over the interval 2004-2006. Using the IAB panel we can identify plant closings in the following manner. As of 2006, we have data on the 'current' state of each establishment that participated in 2004. Of course not all plants 'missing' from the survey in 2006 are deaths: some are establishments where the interviewer is unable to figure out what had happened to them, while other plants will simply be those that have been self-rotated out of the sample.

\footnotetext{
${ }^{9}$ Our results are in line with a consensus that has emerged from empirical studies on offshoring surveyed by Geishecker et al. (2008) and Crinó (2009), as well as the recent investigation by Wagner (2009) who reports employment effects that are either broadly neutral or even modestly benign.

${ }^{10}$ See Wagner (1994) and Heckmann (2009) for an overview of the relevant German literature.
}

Additional information from the German Federal Employment Agency establishment file was then used to check on whether a 2004 participant was still extant in 2006. The file contains information on each German establishment with at least one employee covered by social insurance, and is used to draw the sample for the Establishment Panel. The establishment identifiers of plants with missing data on survival in the panel were compared with the establishment identifiers in the file. A missing establishment was adjudged to have failed if no match could be found in the file. Alternatively put, former missing observations for which a match was found were added back in as survivors. In this way, we were able to obtain virtually complete information on survivals/deaths of all plants that were part of the Establishment Panel in 2004. After all such calculations, we arrive at a total of 199 plant failures for all industries as of 2006 for the organizational change measure of outsourcing. Corresponding plant failures for the ratio of externally sourced inputs to value added are 185 and 120 for the levels and change measures, respectively.

The probability of failure was modeled using a logistic regression in which the RHS variables are identical to those used in the employment change equations. The dependent variable is assigned the value of 1 for those plants that failed between 2004 and 2006, 0 otherwise. All regressors have values set at the time of the 2004 wave.

The logit results are presented in summary form in Table 6 . Beginning with the organizational change measure of outsourcing, we see that all the point estimates are negative, although none achieves statistical significance at conventional levels. The same results obtain for the change in the ratio of externally sourced inputs to value added between 2002 and 2004, that is, all coefficients are again negative and insignificant. For the level of externally sourced inputs in 2004, however, two out of three coefficient estimates are positive (for all sectors and for services). The results for manufacturing are opposite in sign but remain statistically insignificant. Although one might conclude from this evidence that outsourcing might weakly indicate a solution to problems of survivability rather than hinting at a source of competitive difficulty, we would instead incline to the view that there is nothing in the data to suggest that the employment change results reported earlier in Table 3 are subject to survivor bias.

\section{Conclusions}

The results of this investigation into outsourcing and its employment consequences are mixed and may be summarized as follows. First, across all industries, there is no convincing evidence that outsourcing costs jobs. Second, however, behind this latter result is the appearance of disparate effects for services on the one hand and manufacturing on the 
Table 4 The effect of outsourcing on employment change in the services sector, 2002-2004, OLS estimates

\begin{tabular}{llll}
\hline Variable & Specification & \\
\cline { 2 - 3 } & $(1)$ & $(2)$ & $(3)$ \\
\hline
\end{tabular}

Expanded use of bought-in products and services, 2002-2004

$0.057^{* *}$

(0.028)

Ratio of externally sourced inputs to value added, 2002

0.001

$(0.001)$

Change in ratio of externally sourced inputs to value added, 2002-2004

Sales per employee

Export share

Increasing sales expected

Investments in ICT

Investments in production facilities

State-of-the-art technology

Establishment size 21-100

Establishment size 101-1,000

Establishment size 1,001 and more

Wages per employee

Share of high-skilled workers

Separations rate

Share of fixed-term workers

Works council

Collective agreement

Western Germany

Establishment founded before 1990

Single-establishment firm (without subsidiaries)

Legal form (omitted category: sole trader)

Partnership

Limited liability corporation

Company limited by shares

Public corporation

Notes: See Table 1. The mode includes 18 industry dummies ${ }^{*},{ }^{* *}$, and ${ }^{* * *}$ denote statistical significance at the $10 \%, 5 \%$, and $1 \%$ levels, respectively. Robust standard errors are in parentheses

\section{Other legal form}

$$
R^{2}
$$

$N$
$-0.001$

(0.0005)

$5.45 \mathrm{e}-06 \quad 4.00 \mathrm{e}-06 \quad 8.66 \mathrm{e}-06$

$(6.52 \mathrm{e}-06) \quad(6.55 \mathrm{e}-06) \quad(6.23 \mathrm{e}-06)$

$\begin{array}{lll}-0.0003 & -0.0002 & -0.001\end{array}$

$\begin{array}{lll}(0.001) & (0.0006) & (0.0006)\end{array}$

$0.061^{* * *} \quad 0.060^{* * *} \quad 0.060^{* * *}$

$\begin{array}{lll}(0.016) & (0.017) & (0.018)\end{array}$

$0.042^{* * *} \quad 0.043^{* * *} \quad 0.038^{* *}$

$\begin{array}{lll}(0.016) & (0.016) & (0.017)\end{array}$

$\begin{array}{lll}0.019 & 0.020^{*} & 0.023\end{array}$

$\begin{array}{lll}(0.015) & (0.016) & (0.016)\end{array}$

$\begin{array}{lll}0.001 & -0.0001 & 0.002\end{array}$

$\begin{array}{lll}(0.015) & (0.015) & (0.016)\end{array}$

$\begin{array}{lll}-0.002 & -0.001 & 0.007\end{array}$

$\begin{array}{lll}(0.017) & (0.017) & (0.018)\end{array}$

$-0.061^{* *} \quad-0.068^{* *} \quad-0.046^{*}$

$\begin{array}{lll}(0.025) & (0.026) & (0.028)\end{array}$

$\begin{array}{lll}-0.032 & -0.040 & -0.001\end{array}$

$\begin{array}{lll}(0.055) & (0.057) & (0.068)\end{array}$

$\begin{array}{lll}-0.003 & -0,002 & -0.002\end{array}$

$\begin{array}{lll}(0.008) & (0.008) & (0.008)\end{array}$

$\begin{array}{lll}0.003 & 0.004 & 0.021\end{array}$

$\begin{array}{lll}(0.026) & (0.028) & (0.030)\end{array}$

$\begin{array}{lll}0.101 & 0.122 & -0.025\end{array}$

$\begin{array}{lll}(0.052) & (0.053) & (0.064)\end{array}$

$0.106 \quad 0.121^{* *} \quad 0.191^{* * *}$

$\begin{array}{lll}(0.058) & (0.059) & (0.065)\end{array}$

$\begin{array}{lll}-0.005 & 0.002 & -0.0002\end{array}$

$\begin{array}{lll}(0.021) & (0.022) & (0.023)\end{array}$

$\begin{array}{lll}-0.003 & -0.011 & -0.015\end{array}$

$\begin{array}{lll}(0.015) & (0.016) & (0.017)\end{array}$

$0.035^{* *} \quad 0.038^{* *} \quad 0.038^{* *}$

$\begin{array}{lll}(0.016) & (0.017) & (0.017)\end{array}$

$\begin{array}{lll}-0.003 & 0.005 & 0.008\end{array}$

$\begin{array}{lll}(0.015) & (0.016) & (0.016)\end{array}$

$\begin{array}{lll}-0.019 & -0.021 & -0.012\end{array}$

$\begin{array}{lll}(0.017) & (0.017) & (0.018)\end{array}$

$\begin{array}{lll}-0.013 & -0.024 & -0.028\end{array}$

$\begin{array}{lll}(0.024) & (0.025) & (0.026)\end{array}$

$\begin{array}{lll}0.021 & 0.023 & 0.006\end{array}$

$\begin{array}{lll}(0.019) & (0.020) & (0.021)\end{array}$

$\begin{array}{lll}0.032 & 0.032 & -0.032\end{array}$

$\begin{array}{lll}(0.037) & (0.039) & (0.043)\end{array}$

$\begin{array}{lll}0.082 & 0.040 & 0.051\end{array}$

$\begin{array}{lll}(0.079) & (0.086) & (0.103)\end{array}$

$\begin{array}{lll}-0.022 & -0.042 & -0.029\end{array}$

$\begin{array}{lll}(0.043) & (0.045) & (0.046)\end{array}$

$\begin{array}{lll}0.07 & 0.06 & 0.06\end{array}$ $\begin{array}{lll}2,018 & 1,880 & 1,493\end{array}$ 
Table 5 The effect of outsourcing on employment change in the manufacturing sector, 2002-2004, OLS estimates

\begin{tabular}{|c|c|c|c|}
\hline \multirow[t]{2}{*}{ Variable } & \multicolumn{3}{|l|}{ Specification } \\
\hline & $\overline{(1)}$ & (2) & (3) \\
\hline $\begin{array}{l}\text { Expanded use of bought-in products and } \\
\text { services, 2002-2004 }\end{array}$ & $\begin{array}{l}-0.012 \\
(0.015)\end{array}$ & & \\
\hline $\begin{array}{l}\text { Ratio of externally sourced inputs to value } \\
\text { added, } 2002\end{array}$ & & $\begin{array}{l}0.001 \\
(0.001)\end{array}$ & \\
\hline $\begin{array}{l}\text { Change in ratio of externally sourced inputs to } \\
\text { value added, 2002-2004 }\end{array}$ & & & $\begin{array}{l}-0.002^{*} \\
(0.001)\end{array}$ \\
\hline Sales per employee & $\begin{array}{l}-0.0001^{* * *} \\
(0.0003)\end{array}$ & $\begin{array}{l}-0.0001^{* * *} \\
(0.00002)\end{array}$ & $\begin{array}{l}-0.0001^{* * *} \\
(0.00002)\end{array}$ \\
\hline Export share & $\begin{array}{l}0.0001 \\
(0.0003)\end{array}$ & $\begin{array}{l}0.0001 \\
(0.0003)\end{array}$ & $\begin{array}{l}0.0002 \\
(0.0003)\end{array}$ \\
\hline Increasing sales expected & $\begin{array}{l}0.056^{* * *} \\
(0.014)\end{array}$ & $\begin{array}{l}0.054^{* * *} \\
(0.014)\end{array}$ & $\begin{array}{l}0.053^{* * *} \\
(0.014)\end{array}$ \\
\hline Investments in ICT & $\begin{array}{l}0.057^{* * *} \\
(0.014)\end{array}$ & $\begin{array}{l}0.059^{* * *} \\
(0.014)\end{array}$ & $\begin{array}{l}0.059^{* * *} \\
(0.014)\end{array}$ \\
\hline Investments in production facilities & $\begin{array}{l}0.055^{* * *} \\
(0.014)\end{array}$ & $\begin{array}{l}0.056^{* * *} \\
(0.014)\end{array}$ & $\begin{array}{l}0.048^{* * *} \\
(0.014)\end{array}$ \\
\hline State-of-the-art technology & $\begin{array}{l}0.029^{* *} \\
(0.012)\end{array}$ & $\begin{array}{l}0.032^{* * *} \\
(0.012)\end{array}$ & $\begin{array}{l}0.020 \\
(0.012)\end{array}$ \\
\hline Establishment size $21-100$ & $\begin{array}{l}-0.012 \\
(0.015)\end{array}$ & $\begin{array}{l}-0.019 \\
(0.018)\end{array}$ & $\begin{array}{l}-0.011 \\
(0.016)\end{array}$ \\
\hline Establishment size $101-1,000$ & $\begin{array}{l}-0.044^{* *} \\
(0.022)\end{array}$ & $\begin{array}{l}-0.059^{* * *} \\
(0.023)\end{array}$ & $\begin{array}{l}-0.043^{*} \\
(0.023)\end{array}$ \\
\hline Establishment size 1,001 and more & $\begin{array}{c}-0.040 \\
(0.038)\end{array}$ & $\begin{array}{l}-0.058^{* *} \\
(0.039)\end{array}$ & $\begin{array}{c}-0.030 \\
(0.039)\end{array}$ \\
\hline Wages per employee & $\begin{array}{l}-0.011 \\
(0.009)\end{array}$ & $\begin{array}{l}-0.012 \\
(0.009)\end{array}$ & $\begin{array}{l}-0.021^{* *} \\
(0.009)\end{array}$ \\
\hline Share of high-skilled workers & $\begin{array}{l}-0.041 \\
(0.026)\end{array}$ & $\begin{array}{l}-0.044 \\
(0.027)\end{array}$ & $\begin{array}{l}-0.047 \\
(0.027)\end{array}$ \\
\hline Separations rate & $\begin{array}{l}-0.021 \\
(0.055)\end{array}$ & $\begin{array}{l}-0.044 \\
(0.056)\end{array}$ & $\begin{array}{l}-0.024 \\
(0.059)\end{array}$ \\
\hline Share of fixed-term workers & $\begin{array}{l}0.050 \\
(0.065)\end{array}$ & $\begin{array}{l}0.062 \\
(0.067)\end{array}$ & $\begin{array}{l}0.036 \\
(0.085)\end{array}$ \\
\hline Works council & $\begin{array}{l}-0.009 \\
(0.017)\end{array}$ & $\begin{array}{l}0.001 \\
(0.018)\end{array}$ & $\begin{array}{l}-0.019 \\
(0.018)\end{array}$ \\
\hline Collective agreement & $\begin{array}{l}-0.011 \\
(0.013)\end{array}$ & $\begin{array}{l}-0.009 \\
(0.013)\end{array}$ & $\begin{array}{l}0.010 \\
(0.014)\end{array}$ \\
\hline Western Germany & $\begin{array}{l}0.023^{*} \\
(0.014)\end{array}$ & $\begin{array}{l}0.023 \\
0.014\end{array}$ & $\begin{array}{l}0.021 \\
(0.015)\end{array}$ \\
\hline Establishment founded before 1990 & $\begin{array}{l}-0.024^{*} \\
(0.013)\end{array}$ & $\begin{array}{l}-0.025^{*} \\
(0.013)\end{array}$ & $\begin{array}{l}-0.032^{* *} \\
(0.014)\end{array}$ \\
\hline Single-establishment firm (without subsidiaries) & $\begin{array}{l}-0.013 \\
(0.015)\end{array}$ & $\begin{array}{l}-0.014 \\
(0.015)\end{array}$ & $\begin{array}{l}-0.005 \\
(0.016)\end{array}$ \\
\hline Legal form (omitted category: sole trader) & & & \\
\hline Partnership & $\begin{array}{l}0.028 \\
(0.024)\end{array}$ & $\begin{array}{l}0.025 \\
(0.024)\end{array}$ & $\begin{array}{l}0.015 \\
(0.025)\end{array}$ \\
\hline Limited liability corporation & $\begin{array}{l}0.010 \\
(0.017)\end{array}$ & $\begin{array}{l}0.009 \\
(0.018)\end{array}$ & $\begin{array}{l}0.011 \\
(0.018)\end{array}$ \\
\hline
\end{tabular}


Table 5 (Continued)

Notes: See Table 1. The model includes 17 industry dummies ${ }^{*},{ }^{* *}$, and ${ }^{* * *}$ denote statistical significance at the $10 \%, 5 \%$, and $1 \%$ levels, respectively

Table 6 Logit estimates of the effect of outsourcing on plant closings, 2004-2006, summary results
Note: The fitted equations include the full set of regressors used in the previous tables. Standard errors are in parentheses

\begin{tabular}{|c|c|c|c|c|}
\hline \multirow[t]{2}{*}{ Variable } & & \multicolumn{3}{|l|}{ Specification } \\
\hline & & (1) & (2) & (3) \\
\hline \multirow[t]{2}{*}{ Company limited by shares } & & -0.021 & -0.024 & 0.012 \\
\hline & & $(0.033)$ & $(0.034)$ & $(0.036)$ \\
\hline \multirow[t]{2}{*}{ Public corporation } & & 0.043 & 0.044 & 0.040 \\
\hline & & $(0.155)$ & $(0.155)$ & $(0.144)$ \\
\hline \multirow[t]{2}{*}{ Other legal form } & & 0.025 & 0.034 & 0.126 \\
\hline & & $(0.068)$ & $(0.073)$ & $(0.089)$ \\
\hline \multicolumn{2}{|l|}{$R^{2}$} & 0.08 & 0.08 & 0.09 \\
\hline \multicolumn{2}{|l|}{$N$} & 2,523 & 2,433 & 2,002 \\
\hline \multirow[t]{2}{*}{ Outsourcing measure } & & \multicolumn{3}{|l|}{ Sector } \\
\hline & & All industries & Manufacturing & Services \\
\hline \multirow{5}{*}{$\begin{array}{l}\text { Expanded use of bought-in } \\
\text { products and services, 2002-2004 }\end{array}$} & Coefficient (s.e.) & -0.162 & -0.206 & -0.164 \\
\hline & & $(0.281)$ & $(0.357)$ & $(0.473)$ \\
\hline & elasticity (s.e.) & -0.017 & -0.029 & -0.011 \\
\hline & & $(0.030)$ & $(0.051)$ & $(0.031)$ \\
\hline & Observations & 5,551 & 2,662 & 2,772 \\
\hline \multirow{5}{*}{$\begin{array}{l}\text { Ratio of externally sourced inputs } \\
\text { to value added, } 2002\end{array}$} & Coefficient (s.e.) & 0.0002 & -0.047 & 0.006 \\
\hline & & $(0.010)$ & $(0.025)$ & $(0.009)$ \\
\hline & elasticity (s.e.) & 0.0004 & -0.090 & 0.017 \\
\hline & & $(0.023)$ & $(0.048)$ & $(0.025)$ \\
\hline & Observations & 5,282 & 2,561 & 2,609 \\
\hline \multirow{5}{*}{$\begin{array}{l}\text { Change in the ratio of externally } \\
\text { sourced inputs to value added, } \\
2002-2004\end{array}$} & Coefficient (s.e.) & -0.004 & -0.007 & -0.002 \\
\hline & & $(0.013)$ & $(0.016)$ & $(0.018)$ \\
\hline & elasticity (s.e.) & 0.0003 & 0.001 & -0.0002 \\
\hline & & $(0.001)$ & $(0.002)$ & $(0.001)$ \\
\hline & Observations & 3,224 & 1,701 & 1,405 \\
\hline
\end{tabular}

other, and in each case consistent with the aggregate findings these different results derive from different outsourcing measures. These respective (positive and negative) results for the two sectors offer sustenance to the more enthusiastic opponents and supporters of outsourcing alike. But if so, it remains rather thin gruel. Third, it appears that we can reject the notion that the employment consequences are benign by reason of survival bias. That is to say, there are no signs that outsourcing aggravates plant closings.

Further research is required. One limitation of our study is that we were unable formally to account for the possible endogeneity of certain right-hand variables, perhaps most notably investments in ICT. This deficit needs to be tackled with new data sets. Another issue is the impact of outsourcing on productivity and not just employment, tracking similar such studies for Ireland, Italy, Austria, the U.K. and the U.S.A. ${ }^{11}$ The IAB Establishment Panel is integral to this end

\footnotetext{
${ }^{11}$ Daveri and Jona-Lasinio (2008); Geishecker and Görg (2008a, 2008b); Geishecker et al. (2008, 2010); Görg (2005); Girma and Görg
}

because it permits the construction of the relevant time series. Information on insourcing has also been observed since 2008. Use of these new data would allow us to determine potential structural breaks in outsourcing or complementarity between the two forms. Finally, the research effort should also be widen to accommodate differences between domestic outsourcing on the one hand and international outsourcing/offshoring on the other.

\section{Executive summary}

Despite the practice in many western European nations of international outsourcing or offshoring parts of their production processes to low-wage countries being very much in vogue, research on the correlates and consequences of outsourcing using establishment data is still sparse. In this

(2004); Görg et al. (2008a, 2008b); Görg and Hanley (2003, 2005, 2007); Pfaffenrmayr (1999). 
study, German data from the Institute for Employment Research Establishment Panel are used to examine the determinants and consequences of outsourcing. Summarizing our findings with respect to the determinants of outsourcing, there are few overt signs that the phenomena is associated with reduced sales per employee, technological sluggishness, or low wages in offshoring firms. Further, although outsourcing might be viewed as an alternative form of workforce flexibility, our results are not in line with this hypothesis either.

Our findings with respect to the employment consequences are mixed and may be summarized as follows. First, across all industries, there is no convincing evidence that outsourcing costs jobs. Second, some negative effects are reported for manufacturing industry, balanced by positive effects for the service sector. If the results for these two sectors are to be taken as offering sustenance to the more enthusiastic opponents and supporters of outsourcing, it is evidently rather thin gruel. Third, it appears that we can reject the notion that the employment consequences are benign simply by reason of survival bias; that is, there are no signs that outsourcing aggravates plant closings.

Further research is nonetheless required. One limitation of our study is that we are unable formally to account for the possible endogeneity of certain right-hand variables, perhaps most notably investments in ICT. This deficit needs to be tackled with new data sets. Another issue is the impact of outsourcing on productivity and not just employment, taking a cue from extant studies for Ireland, Italy, Austria, the U.K. and the U.S.A. Here the IAB Establishment Panel is integral to this end because it now permits the construction of the relevant time series. Information on insourcing has also been observed since 2008. Use of these new data would allow us to determine potential structural breaks in outsourcing or complementary between the two forms. Finally, the research effort should also be widened to accommodate differences between domestic outsourcing on the one hand and international outsourcing/offshoring on the other.

\section{Kurzfassung}

Obwohl in vielen westeuropäischen Ländern internationales outsourcing oder offshoring in Niedriglohnländer Teil des Produktionsprozesses ist, sind Forschungserkenntnisse über die Korrelationen und Konsequenzen von outsourcing basierend auf Betriebsdaten rar. Im vorliegenden Artikel wurden deutsche Daten des IAB-Betriebspanels genutzt, um die Determinanten und Konsequenzen von outsourcing zu untersuchen. Zusammenfassend zeigen die Ergebnisse bezüglich der Determinanten von outsourcing dass nur wenig darauf hinweist, dass outsourcing mit Lohnsenkung, technischer Stagnation oder Niedriglöhnen in den Unternehmen, die Niederlassungen im Ausland aufbauen, verbunden ist. Außerdem wiedersprechen unsere Ergebnisse den Hypothesen, dass outsourcing als eine alternative Form der Arbeitsflexibilität betrachtet werden kann.

Unter Beachtung der Konsequenzen für die Arbeitnehmer zeigen unsere Ergebnisse folgendes: Erstens kann über alle Branchen hinweg nicht festgestellt werden, dass durch outsourcing Arbeitsplätze verloren gehen. Zweitens werden leicht negative Einflüsse im Verarbeitenden Gewerbe durch positive Effekte im Dienstleistungssektor ausgeglichen. Wenn jedoch die Ergebnisse in diesen beiden Sektoren als Grundlage für enthusiastische Gegner und Befürworter von outsourcing genutzt werden, bewegen sich diese auf dünnem Eis. Drittens scheint es, dass unsere Ergebnisse die Auffassung zurückweisen, dass die Beschäftigungseffekte nur auf einem survival bias beruhen. So deuten die Ergebnisse nicht darauf hin, dass outsourcing die Schließung von Betrieben und Fabriken verstärkt.

Weitere Forschung ist dennoch von Nöten. Eine Begrenzung unserer Studie besteht darin, dass es unmöglich ist, die Endogenität bestimmter Determinanten des outsourcing zu kontrollieren, wie beispielsweise Investitionen in IKT. Dieses Defizit muss mit neuen Datensätzen angegangen werden. Ein weiteres Problem ist der Einfluss von outsourcing auf die Produktivität und nicht allein auf Beschäftigung, worauf Studien in Italien, Australien, U.K. und den U.S.A. hinweisen. Das IAB-Betriebspanel stellt diesbezüglich eine wesentliche Grundlage dar. Informationen über insourcing sind darin ebenfalls seit 2008 enthalten. Die Nutzung dieser neuen Daten erlaubt es potentielle strukturelle Brüche in outsourcing oder in der Komplementarität zwischen diesen beiden Formen festzustellen. Abschließend müssen die Forschungsanstrengungen erweitert werden, um die Unterschiede zwischen inländischem outsourcing auf der einen Seite und internationalem outsourcing bzw. offshoring auf der anderen Seite berücksichtigen zu können. 


\section{Appendix}

Table 7 Description of the variables

Variable Definition

Expanding outsourcing in the last two years

Ratio of externally sourced inputs to value added Change in the ratio of externally sourced inputs to value added

Sales per employee

Export share

Increasing sales expected

Total of all investments

Investments in ICT

Investments in production facilities

Wages per employee

State-of-art technology

Works council

Collective agreement

Western Germany

Number of employees

Share of separations

Share of high-skilled employees

Share of fixed-term employees

New establishment

Single establishment firm (without subsidiaries)

Partnership

Limited liability corporation

Company limited by shares

Public corporation

Other legal form
1/0 dummy: 1 if the establishment said to have been expanding "in buying products and services from outside sources in the last two years."

Ratio of externally sourced inputs to value added.

Change in the ratio of externally sourced inputs to value added.

Volume of sales per employee (In Euros.)

Share of exports in volume of sales.

1/0 dummy: 1 if sales are expected to increase; 0 if "sales stay approximately at the same."

Approximate sum of all investments (in the establishment or in the firm?) (In Euros.)

1/0 dummy: 1 if establishment invested in EDP/ICT; 0 if no investments or investments in other areas.

1/0 dummy: 1 if establishment invested in production facilities, furniture and office equipment; 0 if no investments or investments in other areas.

Gross wages per employee (June) (In Euros.)

1/0 dummy: 1 if the overall technical state of the plant and machinery, furniture and office equipment of the establishment in comparison to other establishments in the same industry is assessed as belonging to the two highest categories on a scale from one to five (viz. "obsolete" to "state-of-the-art"); 0 otherwise.

1/0 dummy: 1 if works council is present; 0 otherwise.

1/0 dummy: 1 if there is either a company or industry-wide wage agreement; 0 otherwise.

1/0 dummy: 1 if plant located in western Germany; 0 otherwise.

Number of employees in the current year (In logs.)

Number of separations as a percentage of total employment.

Share of high skilled in total employment.

Share of fixed-term contract workers in total employment.

1/0 dummy: 1 if establishment/firm created before 1990; 0 otherwise.

1/0 dummy: 1 if single establishment firm; 0 otherwise.

1/0 dummy: 1 if partnership (limited partnership, general partnership, partnership under legal code); 0 otherwise.

1/0 dummy: 1 if limited liability company or limited commercial partnership with a limited company as partner; 0 otherwise.

1/0 dummy: 1 if company limited by shares (public limited company, partnership limited by shares; 0 otherwise).

1/0 dummy: 1 if public corporation, public law foundation, institution, authority or office; 0 otherwise.

1/0 dummy: 1 if other legal form; 0 otherwise. 
Table 8 Descriptive statistics

\begin{tabular}{lrrr}
\hline Variable & \multicolumn{1}{c}{$N$} & Mean & St. Dev. \\
\hline Expanding outsourcing in the last two years & 15333 & 0.110 & 0.313 \\
Ratio of externally sourced inputs to value added & 10624 & 2.421 & 6.578 \\
Change in the ratio of externally sourced inputs to value added & 7768 & -0.082 & 6.841 \\
Sales per employee (kEUR) & 12979 & 166.292 & 572.729 \\
Export share & 14501 & 9.375 & 20.362 \\
Increasing sales expected & 17347 & 0.225 & 0.418 \\
Investments in ICT & 14732 & 0.524 & 0.499 \\
Investments in production facilities & 14732 & 0.500 & 0.500 \\
Wages per employee (kEUR) & 13384 & 1.963 & 1.004 \\
State-of-the-art technology & 9272 & 0.686 & 0.464 \\
Works council & 18708 & 0.337 & 0.473 \\
Collective agreement & 18717 & 0.535 & 0.499 \\
Western Germany & 18753 & 0.673 & 0.469 \\
Number of employees (log.) & 18753 & 3.723 & 1.480 \\
Share of separations & 18714 & 0.066 & 0.274 \\
Share of high-skilled employees & 18751 & 0.659 & 0.268 \\
Share of fixed-term employees & 18699 & 0.043 & 0.115 \\
New establishment & 18578 & 0.597 & 0.491 \\
Single establishment firm (without subsidiaries) & 18512 & 0.724 & 0.447 \\
Partnership & 18510 & 0.075 & 0.263 \\
Limited liability corporation & 18510 & 0.635 & 0.481 \\
Company limited by shares & 18510 & 0.055 & 0.227 \\
Public corporation & 18510 & 0.006 & 0.078 \\
Other legal form & 18510 & 0.021 & 0.143 \\
\hline
\end{tabular}

\section{References}

Abramovsky, L., Griffith, R.: Outsourcing and offshoring of business services: how important is ICT? J. Eur. Econ. Assoc. 4(2-3), 594601 (2006)

Addison, J.T., Bellmann, L., Schank, T., Teixeira, P.: The demand for labor. An analysis using matched employer-employee data from the German LIAB. Will the high unskilled worker own-wage elasticity please stand up? J. Labor Res. 29, 114-137 (2008)

Amiti, M., Wei, S.-J.: Fear of outsourcing: is it justified? Econ. Policy 20(42), 308-347 (2005)

Becker, S.O., Muendler, M.-A.: The effect of FDI on job separation. B.E. J. Econ. Anal. Policy 8, Article 8 (2008)

Becker, S.O., Jäckle, R., Muendler, M.-A.: Kehren deutsche Firmen ihrer Heimat den Rücken? Ausländische Direktinvestitionen deutscher Unternehmen. Ifo-Schnelld. 58, 23-333 (2005a)

Becker, S.O., Ekholm, K., Jäckle, R., Muendler, M.A.: Location choice and employment decisions: a comparison of German and Swedish multinationals. Rev. World Econ. 141(4), 693-731 (2005b)

Bellmann, L., Pahnke, A.: Auswirkungen des organisatorischen Wandels auf die betriebliche Arbeitsnachfrage. Z. ArbeitsmarktForsch. 39(2), 29-40 (2006)

Broedner, P., Kinkel, S., Lay, G.: Productivity effects of outsourcingnew evidence on the strategic importance of vertical integration decisions. Int. J. Oper. Prod. Manag. 29(2), 127-150 (2009)

Crinó, R.: Offshoring, multinationals and labour market: a review of the empirical literature. J. Econ. Surv. 23(2), 197-249 (2009)

Daveri, F., Jona-Lasinio, C.: Offshoring and productivity growth in the Italian manufacturing industries. CESifo Econ. Stud. 54, 414-450 (2008)
Feenstra, R.C., Hanson, G.H.: The impact of outsourcing and hightechnology capital on wages: estimates for the United States, 1979-1990. Q. J. Econ. 114(3), 907-941 (1999)

Geishecker, I., Görg, H.: Winners and losers: a micro-level analysis of international outsourcing and wages. Can. J. Econ. 41(1), 243270 (2008a)

Geishecker, I., Görg, H.: Services offshoring and wages: evidence from micro data. Working paper 1434, Kiel Institute for the World Economy (2008b)

Geishecker, I., Görg, H., Maioli, S.: The labour market impact of international outsourcing. In: Greenaway, D., Wright, P., Upward, R. (eds.) Globalisation and Labour Market Adjustment, pp. 152173. Palgrave, Basingstoke (2008)

Geishecker, I., Görg, H., Munch, J.R.: Do labour market institutions matter? Micro-level wage effects of international outsourcing in three European countries. Rev. World Econ. 146(1), 179-198 (2010)

Girma, S., Görg, H.: Outsourcing, foreign ownership, and productivity: evidence from UK establishment-level data. Rev. Int. Econ. 12(5), $817-832$ (2004)

Görg, H.: International outsourcing and productivity: evidence from the Irish electronics industry. N. Am. J. Econ. Finance 16(2), 255269 (2005)

Görg, H., Greenaway, D., Kneller, R.: The economic impact of offshoring. GEP research report, Leverhulme Centre for Research on Globalisation and Economic Policy, University of Nottingham (2008a)

Görg, H., Hanley, A., Strobl, E.: Productivity effects of international outsourcing: evidence from plant-level data. Can. J. Econ. 41(2), 670-678 (2008b) 
Görg, H., Hanley, A.: Outsourcing helps improve your firm's performance-or does it? J. Financ. Transform. 8, 113-118 (2003)

Görg, H., Hanley, A.: Does outsourcing increase profitability? Econ. Soc. Rev. 35(3), 267-288 (2004)

Görg, H., Hanley, A.: Labour demand effects of international outsourcing: evidence from plant-level data. Int. Rev. Econ. Finance 14(3), 365-376 (2005)

Görg, H., Hanley, A.: International services outsourcing and innovation: an empirical investigation. GEP Working Paper 2007/43, University of Nottingham (2007)

Görzig, B., Kaminiarz, A., Stephan, A.: Wie wirkt sich Outsourcing auf den Unternehmenserfolg aus? Neue Evidenz. Schmollers Jahrb. Wirtsch.- Soz.wiss. 125(4), 489-507 (2005)

Heckmann, M.: Erfolgschancen neu gegründeter Betriebe. IABBibliothek 313, Nürnberg (2009)

Hijzen, A., Görg, H., Hine, R.C.: International outsourcing and the skill structure of labour demand in the United Kingdom. Econ. J. (Lond.) 115(506), 861-879 (2005)

Ohnemus, J.: Productivity effects of business process outsourcing: a firm-level investigation based on panel data. ZEW Discussion Paper 09-088, Centre for European Economic Research Mannheim (2009)

Pfaffenrmayr, M.: Ownership advantages, foreign production and productivity: evidence from Austrian manufacturing firms. Rev. Ind. Organ. 15(4), 379-396 (1999)

Wagner, J.: The post-entry performance of new small firms in German manufacturing industries. J. Ind. Econ. 42(2), 141-154 (1994)

Wagner, J.: Offshoring and firm performance: self-selection, effects on performance, or both? IZA Discussion Paper No. 4605, Institute for the Study of Labor Bonn (2009)

John T. Addison is Professor of Economics at the University of South Carolina. He is a research fellow at New York University School of Law, and the IAB inter al. His current research covers unemployment duration, minimum wages, and worker representation and economic performance. He has published in the major economics and specialty labor journals, including American Economic Review, Review of Eco- nomics and Statistics, Journal of Human Resources, and Journal of Labor Economics. He is the author of several labor economics texts, most recently The Economics of Codetermination: Some Lessons from the German Experience (New York: Palgrave Macmillan, 2009). E-mail: ecceaddi@moore.sc.edu

Lutz Bellmann is head of both the IAB Establishment Panel Project and the IAB Department for Establishment and Employment. Since 2009 he has also been professor of Labour Economics at the FriedrichAlexander-University Erlangen-Nuremberg. Prof. Bellmann has published in international journals such as Industrial Relations, Journal of Applied Social Science and British Journal of Industrial Relations. His current research interests include employer-employee data, econometric studies in labor economics, especially employment, apprenticeship training, further training, industrial relations and labor market effects of foreign firms. E-mail: Lutz.Bellmann@iab.de

André Pahnke studied economic science at the School of Economics and Management of the Leibniz University of Hanover; graduation in 2004. From 2004 to 2010 he was research assistant at the Institute for Employment Research, Nuremberg. Research interests include linked employer-employee data, wages, labor demand, human capital theory, outsourcing, technological and organizational changes as well as industrial relations. E-mail: andre.pahnke@gmx.de

Paulino Teixeira is Professor of Economics at the University of Coimbra, Faculty of Economics, Portugal, and Research Fellow at the Institute for the Study of Labor (IZA), Bonn, Germany. He is concurrently director of $G E M F$, a Portuguese research unit funded by the Foundation for Science and Technology, and editor of Notas Económicas (indexed by EconLit) and Estudos do GEMF (indexed by RePEc). Teixeira has published in a wide range of economics and labor economics journals, including Industrial and Labor Relations Review, Industrial Relations, Journal of Labor Research, Journal of Productivity Analysis, Small Business Economics, and Southern Economic Journal. His immediate research interests are focused on the empirical analysis of unions and works councils, wage determination, human capital, productivity growth, and employment protection. Teixeira received his B.Sc. degree from the University of Coimbra and the Ph.D. from the University of South Carolina, U.S.A. E-mail: pteixeira@fe.uc.pt 